\title{
The Renaissance of Confucianism in Contemporary China from the Perspective of Terror Management Theory
}

\author{
Lu Leng ${ }^{1, *}$, Michael Salzman ${ }^{2}$ \\ ${ }^{1}$ Department of English Teaching, Jinan University, China \\ ${ }^{2}$ Department of Educational Psychology, University of Hawaii at Manoa, USA
}

Copyright $\bigcirc 2016$ by authors, all rights reserved. Authors agree that this article remains permanently open access under the terms of the Creative Commons Attribution License 4.0 International License

\begin{abstract}
Confucianism has been representative of Chinese traditional culture in official context for most of the time since the Han Dynasty (202BC). Since the fall of the Qing Dynasty, China neglected its traditions in order to modernize itself. People seem to be in danger of losing their soul [1]. As capitalism grows in contemporary China, cultural confusion sends China back to its home base - the Confucius worldview and cultural value. People are now exploring ways to integrate Confucianism into modern society. Previous research efforts have explored the motivational reasons contributing to this phenomenon. However, less clear is the psychological and spiritual significance of contemporary aspirations toward resurrecting Confucianism. This paper examines the Confucianism renaissance through the perspective of Terror Management Theory (TMT) which suggests that culture serves as a defense against the anxiety inherent in the human condition. This review is supported by a large body of experimental evidence $[2,3]$. Numerous studies have found that when people are reminded of their mortality, they are motivated to validate and defend their cultural worldviews and values in order to boost their self-esteem and viability of their own culture.
\end{abstract}

Keywords Terror Management Theory, Confucianism, Traditional Culture, Revival

\section{Introduction}

Since the opening-up policy [4] in 1978, China underwent radical and tremendous changes. Chinese people feverishly devoted themselves to developing economy and technology in the past two decades under the delusion that materialism is the path to human happiness. But the most conscientious efforts for prosperity and happiness have produced an effect that the rapid economic gains at the cost of people's morality and humanity [46]. China has experienced a growing gap between the rich and the poor and a rise in corruption, crime, divorce, and most importantly an ideological vacuum [45]. The prosperity has created a moral void and fueled social instability [48]. As the nation enters a new era of increased wealth, people start to search for enduring values.

The Chinese Communist Party (CCP) has increasingly promoted the ancient sage Confucius (孔子, 511-479BC) as the cure for social ills because of his deeply established values and enlightening philosophy such as benevolence (ren 仁), righteousness ( $y i$ 儀), propriety ( $l i$ 禮), wisdom (zhi 智), sincerity (xin 信) that ensure human growth and cultural continuity. As the core of Chinese culture, Confucianism has "thoroughly penetrated every dimension and stratum of traditional society and its institutions" [1]. It seems to meet the psychological needs of the Chinese who are facing uncertainty from social, economic, and cultural transformation and from the rising pressure of unstable markets that are both regulated by the government and the economy.

Actually the Confucianism was denounced in the 1920s in the May Fourth movement [5], a landmark event in modern Chinese history, where a new generation rejected Confucianism and traditional Chinese culture. Later MaoTseTung tried to wipe out Confucian feudal teaching during the tumultuous Cultural Revolution [6] from 1966 to 1976. The re-appreciation of Confucius came back in the wake of the 1989 Tiannamen Square [7] demonstration where students showed their respect and appreciation for the traditional Chinese culture. This event marked a rediscovery of Chinese tradition and culture that Maoism had tried to abolish.

Now the Confucius figure is even more rehabilitated as the Chinese experiencing cultural contradiction and spiritual confusion [8]. There is much evidence that Confucianism is undergoing a multi-faceted revival in contemporary China. It is seen in people's life and education field, such as televisions, public slogans, buses and subways, schools, and academia. Why is there a national fascination and enthusiasm with Confucianism? And why is Confucianism heralded as a solution to the many political, social, economic, and ethical problems that China faces? This article examines these research questions from the existential framework provided by terror management theory and research. 


\section{Research Purpose and Objectives}

The complex psychological reasons on the renaissance of Confucianism require deeper analysis. Past research efforts on the revival of Confucianism have so far been examined from the perspective of globalization [9] and education [10, 11], focused on Confucianism's political nature [12] and revival trends and categories in China [13]. Researchers have analyzed Confucianism from the cultural perspective [14] and religious beliefs [15]. The paper represents an important attempt to explore the deep reasons that cause the resurgence of traditional culture in light of terror management theory (TMT). More specifically, we will use a TMT analysis to help comprehend the psycho-dynamics of the revival phenomenon and the motive of the Chinese to recover, reconstruct, and apply Confucianism to current realities. Through this paper review, the readers are hopefully to understand the psychological and cultural reasons why Chinese people are now returning to the sage for wisdom and spiritual enlightenment, and why culture is a source of resilience that promotes people's psychological and social well-being.

\section{Analysis}

The $20^{\text {th }}$ century has seen a decline in Confucian morality in Mainland China due to the denigration of Chinese traditional culture and thoughts. In 1905, the Qing Empire took a great effort to abandon the ubiquitous civil-service exam system, which the higher education system was based on for more than 1,300 years. This was followed with the collapse of the last Qing dynasty in 1911. In 1915, Chinese intellectuals Chen Duxiu, Cai Yuanpei, Li Dazhao, Lu Xun, Zhou Zuoren, and Hu Shi inaugurated a "New Culture Movement" (xin wenhua yundong 新文化運動) that revolted against Confucianism. They called for a creation of a new Chinese culture based on global and western standards, especially democratic and egalitarian values and science. The simplified new Chinese character was created in that movement. The young followers especially favored individual freedom and woman liberation. The Doubting Antiquity School [25] re-examined the Confucian texts and ancient classics using modern textual and critical methods. Angel[26] commented that the "New Culture Movement" was a more pervasive cultural revolution than the later Maoist movement of that name.

The values of modern civilization continued to rise. China's $20^{\text {th }}$ century was distinctly unkind to the Confucian worldviews. In 1919, the May Fourth Movement called the "Down with the Confucian School" (dadao kongjiadian 打 倒孔家店). Scholars criticized Confucian heritage as China's barrier to its modernization and quest for power and wealth in competition with the nations of the world [27]. After the founding of the People's Republic of China in 1949, the Confucius culture was again dwarfed by political movements and economic development. In the Cultural
Revolution (1966-1976) the anti-Confucian crusade reached a crescendo. The revolutionary leader MaoTseTung kicked off a campaign to "Criticize Lin Biao and Confucius". Confucianism was regarded as old thinking, old culture, old customs and old habits [45]. It among various schools of thoughts was most fiercely attacked and condemned because its troublesome nature on her way toward economic prosperity and science development. Confucian temples throughout China were damaged by young Red Guards and Confucian scholars were criticized and persecuted into silence [28]. Since then Confucianism in Mainland China had become virtually extinct in the late $20^{\text {th }}$ century.

The ideological emancipation of the last 1970s, advocated by Deng Xiaoping, significantly changed the mindset of China's more than a billion citizens, unveiling a new era of creativity and productivity [29]. Yet it had also plunged Chinese society into political puzzlement and a moral vacuum [46]. Philosophers and educators like Liang Shuming (1893-1988) and Mou Zongsan (1909-1995) developed new Confucian ideas and taught its relevance to modern China. Neo-Confucian scholars in Hong Kong, Taiwan, and the United States, reacting to mainstream scholarship and dominate ideologies, have attempted to carry the burden of preserving and reviving the endangered Chinese cultural and scholarly tradition [30]. People began to seek spiritual values in everyday life, asking, "What should be the values of today?" and pondering where China is morally and politically heading [31].

The CCP has largely accepted the country's enthusiasm for Confucius. The CCP chiefs made a decision on cultural reforms in Oct. 2011, which confirmed a shift in the party from emphasizing the economic growth to addressing the country's psychological and social well-being challenges. The goal of the cultural reform is to build up China citizen's confidence and consolidate its people's soul. Many people believe that the philosophical system of Confucius can provide an ethical code that now seems to be lacking in Chinese society.

Nowadays, more and more scholars publicize "country cultural learning" (guoxue 國學), “Confucian learning" (ruxue 儒學), and practice Confucianism as a "reservation zone" for the revival of family bonding and moral conscience. Professors who give lectures on traditional culture including Confucianism, Taoism, and Buddhism at national television channels become well-known scholars overnight. Di Zi Gui (弟子規), San Zi Jing (三字經), Confucius Analects (論語) become mandatory reading materials in Chinese literature courses. Classical recital classes (guo xue ban 国学班) for children spring up quickly in many parts of the country. Thousands of books and DVDs on Confucianism and traditional culture and philosophy sprouted, along with academic interests. Confucian businessmen (rushang 儒商) and benevolent officials are highly praised by the public. More and more people refer to the Chinese sages such as Confucius (孔子), Mencius (孟子), Zhuang Zi (莊子), and Xun Zi (荀子) to acquire practical wisdom. The ancient teachings of 
Confucius, centering on virtue and harmony, are finding a new resonance amid the chaotic and rapid development of modern China.

The nation finally realizes that the 2,500-year tradition and value still permeate the new China. "The Chinese spirit was mainly identified with the Confucian spirit as it was traditionally understood" [46]. In the Confucius culture, people find a sense of connectedness and belongingness. Confucian tradition in a sense is a source of national stability, unity and prosperity. The Confucian cultural worldviews suggest the value of life and the meaning of being. It provides people with the fortitude to carry on humanitarian outlook, moral perfection and self-improvement [32]. It is also a pillar in the country's economic, social, and spiritual development.

Chinese people are restoring the cultural foundations of their lives and resurrecting the ontological standards and values embedded in their bones. How can we understand this motive? TMT provides good insights in comprehending this phenomenon. The TMT suggested that there maybe circumstances under which individuals cannot maintain the cultural anxiety buffer either because they cannot maintain a sense of value within the cultural drama, or because they can no longer sustain faith in the cultural drama itself. One possibility for such people is to find an alternative cultural worldview that is more compelling and better enables them to obtain self-esteem. The accession to the conversion pressures of the dominant worldview may be seen in this light too [2]. The following section will explain that when the structure of the cultural worldview is severely compromised, shattered and invalidated, as in the case of the Cultural Revolution and fast economic development experienced by the Chinese, how and why they recognize and recover the values of Confucianism.

\subsection{Terror Management Theory}

TMT suggests that human beings use self-esteem and cultural worldviews to defense against deeply rooted anxiety in human existence [16]. Self-esteem and culture form a dual-component anxiety buffer. "The only or most important reason that people fear death or that a fear of uncertainty lies at the root of the need for self-esteem and faith in one's cultural worldviews" [17]. Empirical studies support this claim. For example, morality salience has been found to lead to people's increased striving for self-esteem [18].

Since self-esteem can only be constructed in a meaningful world, it is vital to understand how self-esteem is constructed differently across cultures. It has been proposed that in collectivist cultures, self-esteem is mainly based on the ability to adjust to the needs of others and to maintain harmony within the social context [19]. Self-esteem is a pervasive force for human motivation, which is obtained by confident belief in a socially constructed cultural worldviews and meeting or exceeding the internalized standards of value that are derived from the culture [17].
Because self-esteem serves as a psychological defense against the terror inherent in the human condition, people are normally motivated to maintain high levels self-esteem and protect their self-esteem when it comes under threat.

Culture(s) provide durable sources of self-worth and offer insights into people's psychological and behavioral reactions to the realization of their inevitable mortality [17]. TMT theorists and researchers [20] inspired by Becker $[21,22]$ argued that "cultural worldviews that give life meaning and permanence, give us the opportunity to view ourselves as valuable beings, and provide some hope of transcending death." Cultural institutions "enable people to feel part of something larger, more significant, and more eternal than their own individual lives through connections and contributions to their families, nations, professions, and ideologies" [17]. It can also be seen as an anxiety buffer against the existential terror intrinsic to anxiety-prone human beings. The cultural anxiety buffer consists of worldviews and values that provide self-esteem and a meaningful life. The ongoing pursuit of self-esteem and worldview validation is a part of the system that human beings use to both regulate their behavior and cope with their existential situation.

We are faced with the existentially essential questions of why to live and how to live. Culture(s) address these questions. Cultures provide a description of reality (cultural worldviews) and a roadmap for living within that worldview. Cultural worldviews vary widely but all seem to offer [2]:

- A description of how the world was created

- Prescriptions for what people should to live a good life and to be of value in a meaningful world

- $\quad$ Some promise of immortality literal (as in eternal life) or symbolic by contributing to something larger that self that continues past one's mortal life (as in the nation and its symbols)

- What kind of persons we should strive to be to achieve value in a culturally prescribed (and internalized) world of meaning.

Cultural loss and cultural trauma assault the world of meaning largely constructed by culture(s). Culture(s) serve as a central mechanism for buffering human existential anxiety. An implication of this perspective is that if a person loses faith in his prescribed cultural worldview, he is likely to be susceptible to anxiety and related symptoms [23]. The shattering of a cultural worldview that previously offered psychological sustenance exposes humans to unmediated existential terror that motivates either a bolstering of that cultural worldview or conversion or reconnection to bedrock cultural values and behavioral prescriptions [24].

\subsection{Why the Confucianism Revives through Terror Management Theory}

In the $20^{\text {th }}$ century, many of the Chinese people wanted to accept the superiority of Western science, democracy and prosperity. Then they fanatically developed the country's economy and took efforts to adapt to the industrialization 
and Western worldviews. This movement was fueled by globalization and technological innovation. The finance capital and economic benefits became powerful forces reshaped the world [33]. The Chinese began to pursue maximization of profit and economic benefit without regard to national identity and social consequences. The long-honored Chinese values, such as refining personal morality and harmonizing mankind and nature are gone with the material pursuit. The Chinese lost the way to their spiritual home [1].

The pursuit of materialism, encroaching Westernization, weakened Confucianism, and disillusionment with communism has left many Chinese with chaotic values and cultural crossroads. The Cultural Revolution caused millions to lose faith in the Marxist-Leninist-MaoTseTung thoughts. The subsequent destruction of the traditional culture, "a vital source of existential meaning" [23] brought the Chinese deep psychological suffering and anxiety. In addition Deng Xiaoping proposed the idea "to be rich is glorious", people then began to adopt consumerism and materialism. After that they thought self-esteem came from developing economy and adapting to Western worldviews, yet in the end they realized that these "favorite" pursuits created more grief, pain and tragedy. Because it was opposed to the conception that serving the people is a pathway to a sense of personal significance and self-esteem. The traumatic disruption of culture and the resultant breakdown of the meaning and value for the Chinese finally fueled the rise of Confucianism with its deep roots in Chinese culture and history in the mid-1980s. It helped recover traditional culture and a sense of long lost dignity and pride in people's heart.

The famous Confucian scholar Jiang Qing[34] argued that the right and effective way for Chinese to tackle such problems is to cultivate and regain the lost standards of public conduct. People need to nurture something deep from their heart and soul. It is in this sense that all five-core Confucian values, with the right emphasis on humanity (仁), righteousness (義), propriety (禮), wisdom (智) and trust (信) can help China develop a sense of responsibility for man's proper relationship to himself, his community, the state, the nature, and the world.

Modern Western values of liberty, rationality, due process of law, human rights and dignity, independence and autonomy of the individual, "while overwhelming, was never compelling enough to attract the faith required to establish an adequate cultural anxiety buffer" in the Chinese [23]. Western values, liberty, rationality, legality, rights, and individual dignity seem as opposed to Confucian values, discipline, sympathy, humanity, responsibility, social solidarity, and virtue. It is difficult to bring about an enduring social order and peace in China because of these fundamental cultural and religious differences. Confucianism, which focuses on the cultivation of virtue and maintenance of ethics, has long embodied the ideals of Chinese. It is "sedimented into Chinese people's psychological being: it forms the 'deep structure' of their thinking" [1]. The 2,500-year tradition permeates Chinese society and culture in ways that many may not even realize.

"From a TMT perspective, efforts toward cultural recovery and a reconstruction of a world of meaning represent an important step towards the restoration of the essential psychological prerequisites for adaptive action" [23]. A principle and well-tested hypothesis of TMT (the anxiety buffer hypothesis) states that if a psychological structure provides protection against anxiety then augmenting that structure should reduce anxiety in response to subsequent threats [35]. Chinese people are seeking to identify and operationalize bedrock principles and values that define their being and guide their action to achieve the anxiety-buffering effects of self-esteem [36].

Many people allege that there are "growing pains" in the nation's urbanization and modernization process. The commodity fetishism drives people away from the traditional agricultural values such as the oneness between nature and man, community spirit, and filial piety. A trend of nostalgic sentimentalism is common in this fast changing society. Some people long to bring back the "good old days" when market reform did not shatter some entrenched values that nourish their soul. The striving process of restoring and reconstructing Confucianism that have laid the ideological and moral foundation of Chinese society is a psychological renewal, a revalidation of Chinese people's worldview and their standards for being and living in the world. They try to achieve the culturally prescribed standards of being and acting in the world, which enhances their self-esteem and makes them believe that they are indeed live in a meaningful world. Their wandering souls are returning back home.

\section{Discussion}

While Chinese people spend many years creating booming economy, technology, and national power, they spend little time becoming a cultural entity. When they pay overwhelming attention to material abundance, they fail to preserve and carry on its great culture and civilization. Under the background of rapid societal changes, the Chinese people commonly lament the fading or absence of "trust" and "belief" in social intercourse [15]. The main risk to China's future growth lies in the disharmony between economic growth and social development.

Economic growth has resulted in many social problems and challenges that have yet to be solved [29]. The challenge for China now is to revolve the tension between tradition and modernity [37]. And the Chinese, from the top officials to the common people should put more efforts in cultivating benevolence, justice, humanity, morality and social harmony, the core values of Confucianism [47]. However new development of Confucianism must adapt to a world that is radically different from imperial China. Neither all things 
associated with feudal times should be abandoned nor all Confucian worldviews are perfect. Many theories in Confucianism actually conflict with the laws of modern society. Some of his ideas are outdated, such as the three obedience: to father before marriage, to husband after marriage and to son after the death of one's husband, the power-based doctrine, the order of a rank society by indicating the divine right of emperors, and social values that require people to be docile. Chinese people should absorb the essence and cast away the bad values in order to adapt to the modern world. The Confucius teachings for heaven and human harmony, self-improvement, hard work, and being a man of integrity and modesty are worthy of contemporary endorsement and development.

The renaissance of Confucianism has won both supporters and detractors. Some scholars argued that the Confucius revival is rather a political use of China's traditions by the party-state [49]. It is a top-down cultural renaissance movement. The Confucius philosophy in emphasizing social order, family harmony and moral instruction and transformation sit well with the Chinese government's development plan [48]. The Confucian-legalist political system served as a sacred foundation in China for more than 2,000 years [50]. Thus the revival of Confucianism is mainly the political leaders' initiative and propaganda. Furthermore with the introduction of Western religions such as Christianity, people began to think about the relationship between Confucianism and religion. Jiang Qing proposed that there had always been a competitive relationship between Chinese and Western cultures and religions: while one rises, the other falls, so empty talk of "harmonious religion" will only "cover up the hegemonic expansion of powerful foreign religions" [52]. Kang Youwei argued that Confucianism is a state religion, and he believed that "teaching" (jiao) of Confucianism encompasses both the didactic-transformational significance of traditional Chinese rites and the religious significance of "spiritual-human communication" [54]. Yet nowadays, many common people and intellectuals have renewed appreciation of the strength and power of Christianity, and this faith satisfies their spiritual longing [55]. Only time will tell whether the religious significance of Confucianism or the Christianity can exert long lasted impact on Chinese people's spiritual lives and mundane experiences [53]. However Judith Berling maintained that "Confucianism is often characterized as a system of social and ethical philosophy rather than a religion...Confucianism was part of the Chinese social fabric and way of life; to Confucians, everyday life was the arena of religion" [56]. So the sage Confucius never faded away from people's life through this perspective. Yet the key question how much of Confucianism is still alive in China today still provokes hot debates.

TMT researchers suggested that a cultural construction serves the essential function of buffering anxiety-prone humans against the potentially paralyzing terror that may result from an unmediated awareness of morality [2].
Humankind is metaphysical beings searching for an ultimate meaning of life. They can work, in communities, nations and world to construct and provide positive pathways to significance and to a "constructive heroism" because they strive for significance [36]. Humans are able to live and die for the sake of his values and ideals. The striving for meaning in life is their primary motivational force to live [38]. This spiritual desire reflects the special demands of human existence beyond material gains [46].

TMT theory shows that an attack on the worldview or ideology increases death thought accessibility and motivates cultural worldview defense. If people are under extreme attack or trauma (i.e, Cultural Revolution) it may motivate the abandonment of faith and return to bedrock or conversion to another "faith" [23]. Instead of pursuing the Western values, the Chinese now realize that they must first rebuild their cultural identity before they can make themselves more respected in the world and more united in case of a crisis. The traditional culture provides an enormous impetus to the national rejuvenation in front of the rising tide of cultural globalization. The reason why the Chinese civilization can endure for five thousands of years may due to its cultural continuity. If Chinese people want to realize the "great rejuvenation" and the "Chinese dream" [39], they need to base their values on a sense of national identity and the innovating Confucianism [40].

This year marks the 2566th anniversary of Confucius' birthday. While alive, the sage was not accepted by his society. His beliefs were met with the curse of ridicule and prejudice and his life was crippled with harsh conditions and setback. In $21^{\text {st }}$ century, a new age of Confucian Renaissance is now dawning as research institutes and colleges flourish all over the world. Scholars $[1,41]$ have argued that the revived Confucianism has become the modern Chinese nationalism and contemporary forms of Chinese spirituality. The quest of humanity will advance into new frontiers at the speed of light, and society will continue in its rollercoaster journey with its new discoveries of the past [42]. Nevertheless, the revival of Confucianism is a long-term process. Traditional Confucianism needs a space where it can grow slowly and thrive [43].

\section{Conclusions}

This paper presents an existential analysis of China's revival of Confucianism and the effects of cultural recovery in the current era of national rejuvenation. In terms of the essential psychological functions of TMT, the motive for Chinese people to restore Confucianism and traditional cultures can be well understood in the context of the essential anxiety-buffering function offered by culture. TMT suggests that we human beings have existential anxiety, which is a "terror" rooted in the human condition. The anxiety rumbles in the background of our conscious lives and that threatens to immobilize us if unmediated and 
unbuffered by the conviction that we have value in a meaningful world. What we believe about that fact and our conceptions of what follows varies across cultures. How do I be and what do I do given the reality that we cannot fulfill the basic biological motive that we share with all life that is to continue existence. How do I function within this basic human problem is a question raised by almost every human being. Culture provides a roadmap that people can follow and a vital source of existential meaning guiding people's behavior [36].

Cultural worldviews and people's identity and self-esteem serve as a psychological defense against the anxiety and terror inherent in human world. With the promulgation of the Open Door Policy [44], commercialism and consumerism collide with the Chinese's traditional values from the old way of life, family laws, kinship and traditional culture. Many people are spiritually deprived and lack manners and morals. Consequently people realize that Confucianism could be the best way to help the Chinese rebuild values and address spiritual losses since it is the bedrock of their civilization and ideological source. An essential function of Confucianism is to make continued self-esteem in Chinese people accessible. The Confucius worldviews give people a place where they belong and where can be supported, yet whether the innovating Confucianism could set people in a motion to a genuine transformation still needs to be examined.

This theoretical review provides a foundation to understanding the core values of Confucianism and offers a valuable perspective on what has been happening in the past 40 years or so under the banner of Confucianism. It provides unique perspectives on the challenges facing China's future. The Chinese society has undergone dramatic transformations and the current ruling ideology of Marxism is losing support. The dilemma faced by the Chinese is that they realized the urgent need for restoring their cultural and national identity but at the same time the trend of modernity and the ideology of liberal democracy prevented them from reviving the past. How to connect tradition with modernity and globalization and even transcend these elements is a challenge that needs to be addressed. The paper also provides new insight into how cultural worldviews and human beliefs influence the thoughts, attitudes and behaviors for the Chinese in the era of spiritual vacuum and ideological collapse [51].

\section{REFERENCES}

[1] J. Makeham. Lost Soul: "Confucianism" in Contemporary Chinese Academic Discourse, Harvard University Asia Center for the Harvard-Yenching Institute, Cambridge, Mass, 2008.

[2] S. Solomon, J. Greenberg, T. Pyszczynski. Terror management theory of self-esteem. In C. R. Snyder \& D. R. Forsyth (Ed.), Handbook of Clinical and Social Psychology,
The Health Perspective, Vol.162, 21-40, Pergamon Press, Elmsford, NY, 1991.

[3] J. Greenberg, S. L. Koole, T. A. Pyszczynski. Handbook of Experimental Existential Psychology, Guiford Press, New York, 2004.

[4] L. Q. Li, Breaking through: The Birth of China's Opening-up Policy, Oxford University Press, New York, 2009.

[5] Q. Zhao. A review of studies of the May Fourth Movement in China over the past decade, Chinese Studies in History, Vol.43, No.4, 73-89, 2010.

[6] R. Mitter. A Bitter Revolution: China's Struggle with the Modern World, Oxford University Press, New York, 2004.

[7] T. Plafker. Chinese government urged to open dialogue on 1989 Tiananmen Square protests, The Chronicle of Higher Education, Vol.45, No.28, 51, 1999.

[8] Y. C. Guo, J. J. Lei. An outline of the cultural contradiction and spiritual confusion of Chinese intellectuals in the $20^{\text {th }}$ century. Journal of First Teachers College of Hunan, Vol.8, No.4, 116-118, 2008.

[9] Y. Wu, D. A. Bell. The revival of Confucianism in an age of globalization - Towards a critical Confucianism, OMNES 제 5 권 제 1 호, 1-21, 2014.

[10] A. Onsman. Recognizing the ordinances of Heaven: the role of Confucianism in higher education management in the People's Republic of China, Journal of Higher Education Policy and Management, Vol.34, No.2, 169-184, 2012.

[11] T. L. Yu. The revival of Confucianism in Chinese schools: a historical-political review, Asia Pacific Journal of Education, Vol.28, No.2, 113-129, 2008.

[12] S. F. Wu. The revival of Confucianism and the CCP's struggle for cultural leadership: a content analysis of the People's daily, 2000-2009, Journal of Contemporary China, Vol.23, No.89, 971-991, 2014.

[13] Y. F. Li, H. Yue. A new analysis of the revival of Confucianism, Journal of Changchun Institute of Technology, Vol.12, No.1, 5-7, 2011.

[14] K. J. Hammond, J. L. Richey, The sage returns: Confucian revival in contemporary China, Albany, SUNY Press, 2015.

[15] B. Sebastien, T. Joel. The contemporary revival of Confucianism: Anshen Liming or the religious dimension of Confucianism, China Perspectives, Issue75, 88-106, 2008.

[16] T. Pyszczynski, J. Greenberg, S. Solomon. A dual process model of defense against conscious and unconscious death-related thought: An extension of terror management theory, Psychological Bulletin, No.106, 835-845, 1999.

[17] T. Pyszczynski, J. Greenberg, S. Solomon. J. Arndt, J. Schimel. Why do people need self-esteem: a theoretical and empirical review, Psychological Bulletin, No.130, 435-468, 2004.

[18] J. Greenberg, L. Simon, T. Pyszczynski, S. Solomon, D. Chatel. Terror management and tolerance: does mortality salience always intensify negative reactions to others who threaten one's worldview? Journal of Personality and Social Psychology, No.63, 212-220, 1992.

[19] H. R. Markus, S. Kitayama. Culture and the self: implications for cognition, emotion, and motivation, Psychological Review, Vol.98, 224-253, 1991. 
[20] T. Pyszczynski, S. Solomon, J. Greenberg. In the wake of 9/11: The psychology of terror. American Psychological Association, Washington, DC, 2003.

[21] E. Becker. The Birth and Death of Meaning, Free Press, New York, 1971.

[22] E. Becker. The Denial of Death, Free Press, New York, 1973.

[23] M. Salzman. Cultural trauma and recovery: perspectives from terror management theory, Trauma, Violence and Abuse: A Review Journal, Vol.2, No.2, 172-191, 2001.

[24] M. Salzman. Globalization, culture, and anxiety: perspectives and predictions from terror management theory, Journal of Social Distress and the Homeless, Vol.10, No.4, 377-352, 2001.

[25] D. Bary, W. Theodore. Sources of Chinese tradition: From 1600 through the twentieth century, Columbia University Press, 2001.

[26] S. C. Angel. Confucianism on the comeback: current trends in culture, values, politics, and economy, Social Education, Vol.74, No.1, 24-27, 2010.

[27] A. Chen. Three political Confucianism and half a century: The Renaissance of Confucianism in Contemporary China, Springer, New York, 2011.

[28] P. Mooney. Confucius comes back, Chronicle of Higher Education, Vol.53, No.33, 2007.

[29] A. G. Hu. China in 2020: A New Type of Superpower, Brookings Institution Press, Washington, D.C., 2011.

[30] Q. Jiang. From Mind Confucianism to Political Confucianism: The Renaissance of Confucianism in Contemporary China, Springer, New York, 2011.

[31] R. P. Fan. The Renaissance of Confucianism in Contemporary China, Springer, New York, 2011.

[32] Q. Jiang. Introduction to Gong Yang Confucianism, Liaoning Education Press, Shen Yang, 1995.

[33] Greider, W. One World, Ready or Not: The Manic Logic of Global Capitalism, Simon \& Schuster, New York, 1997.

[34] Q. Jiang. Reflections on the establishment of Confucianism as the state religion of China, Communication in the Study of Confucianism, Vol.1, 3-7, 2005.

[35] J. Schimel, J. Hayes, T. Williams, J. Jahrig, M. Charles. Is death really the worm at the core? Converging evidence that worldview threat increases death-thought accessibility, Journal of Personality and Social Psychology, Vol.92, No.5, 789-803, 2007.

[36] M. Salzman. Globalization, religious fundamentalism and the need for meaning, International Journal of Intercultural Relations, Vol.32, No.4, 318-327, 2008.

[37] L. Chen. Tradition and Modernity A Humanist View, Brill Press, Boston, 2009

[38] R. W. Hood, P. C. Hill, W. P. Williamson. The psychology of Religious Fundamentalism, Oxford University Press, New York, 2005.
[39] D, Kerr. China's Many Dreams: Comparative Perspectives on China's Search for National Rejuvenation, Houndmills, Basingstoke: Palgrave Macmillan, 2015.

[40] L. W. Zhang. On innovation of Confucianism, Journal of Renmin University of China, Vol.29, No.3, 141-147, 2015.

[41] J. Berthrong. Lost soul: 'Confucianism' in contemporary Chinese academic discourse, China Journal, Issue61, 146-147, 2009.

[42] P. W. Ma. Introduction: Confucius the Sage on the Road, Better Link Press, New York, 2010.

[43] D. Lin. On One-continuity in Jiang Qing's Confucian Thought: The Renaissance of Confucianism in Contemporary China, Springer, New York, 2011.

[44] K. B. Bucknail. China and the Open Door Policy, NC: Boson Books, Raleigh, 2012.

[45] F. Fallman. Useful Opium? 'Adapted religion' and 'harmony' in contemporary China, Journal of Contemporary China, Vol.19, No.67, 949-969, 2010.

[46] Z. H. Chen. On the cultural foundation of moral construction, Journal of Shanghai Normal University, Vol.36, No.5, 1-7, 2007.

[47] J. Y. Lin. China's economic development and cultural renaissance in the multipolar growth world of the twenty-first century, China Economic Journal, Vol.6, No.1, 1-11, 2013.

[48] The Economist. Sage move? China and Confucius, Vol.399, No.8731, 44, 2011.

[49] J. Ai. Politics and traditional culture: The political use of traditions in contemporary China, Singapore: World Scientific Publishing Company, 2014.

[50] D. X. Zhao. Neo-Confucianism and the advent of a "Confucian Society", The Confucian-Legalist State, Chapter 13, Oxford University Press, 2015.

[51] Q. Jiang. Thoughts on rebuilding Chinese Confucianism, Politics of the Kingly Way and Confucian Constitutional Government: Confucian Perspective on the Future Development of Chinese Governance, Xiuwen, Guizhou: Yangming jingshe, 373-374, 2010.

[52] Z. Ren, M. Liu. The returning of Confucianism: Dialogue, China University of Political Science and Law Press, 2012.

[53] C. S. Gan, Y. Q. Zhou. The religious nature of Confucianism in contemporary China's "Cultural Renaissance Movement", Contemporary Chinese Thought, Vol44, No.2, 3-15, 2013.

[54] Co-organized by Chen Ming and Guangdong's Xinfu Education Group, this meeting marked the first occasion when an academic conference on the theme of "Confucian religion" was held in mainland China, and it received much media attention.

[55] K. M. Kwan, S. Y. Han. The search for God in Chinese culture and contemporary China, Canadian Social Science, Vol.4, No.3, 27, 2008.

[56] J. Berling. Confucianism. Retrived from www.kenyon.edu/D epts/Religion/Fac/Adler/Reln270/Berling-Confucianism.htm (accessed April 12, 2012). 